Prophetic: Professional, Empathy and Islamic Counseling Journal

Vol. 2, No. 01, Juni 2019, hlm. 83-94

e-ISSN : 2685-0702, p-ISSN : 2654-3958

Tersedia Online di http://syekhnurjati.ac.id/jurnal/index.php/prophetic

Email: prophetic@syekhnurjati.ac.id

\title{
Kolaborasi Konseling dengan Kesehatan Jiwa
}

\author{
Asriyanti Rosmalina \\ Program Studi Bimbingan Konseling Islam, Fakultas Ushuluddin Adab dan Dakwah, \\ IAIN Syekh Nurjati Cirebon \\ rossmalina@yahoo.com
}

\begin{abstract}
Abstrak
Pesatnya perkembangan di segala bidang telah memberikan dampak yang signifikan bagi seluruh umat manusia. Perkembangan bidang teknologi, komunikasi dan transportasi memungkinkan individu untuk berinteraksi atau berkomunikasi dengan individu lain, bahkan di belahan dunia lain dengan mudah. Di sisi lain ternyata melahirkan dampak yang kurang menguntungkan, yaitu makin menggejalanya berbagai problema yang bersifat kompleks, baik bersifat personal atau sosial. Kehidupan yang terlalu berorientasi pada kemajuan dalam bidang material (pemenuhan kebutuhan biologis) telah menelantarkan supra empiris manusia sehingga terjadi pemiskinan ruhaniyah dalam dirinya.
\end{abstract}

Kata Kunci: Konseling; Kesehatan; Jiwa.

\section{PENDAHULUAN}

Perkembangan teknologi telah memudahkan para ahli bidang kedokteran dalam melakukan pekerjaannya. Perkembangan teknologi juga telah menyebabkan munculnya penyakit dari infeksi mengarah kepada penyakit degeneratif yang notabene lebih sulit diatasi. Hal tersebut sangat membutuhkan bidang konseling untuk membantu bidang kedokteran untuk mengobati penyakit generatif tersebut. Pelaksanaan konseling (helping relationship) sebenarnya bukan hanya terjadi dalam setting pendidikan (formal) saja, tetapi juga dalam semua bidang kehidupan dimana terjadi hubungan antar manusia dengan manusia

Dalam bidang kesehatan, modernisasi di bidang teknologi telah membantu para dokter dalam diagnosis dini, pencegahan, dan pengobatan pasien. Namun di sisi lain modernisasi, terutama perubahan gaya hidup dan kerusakan lingkungan akibatperubahan sistem agraris menjadi industri, telah menimbulkan pergeseran penyakit dari infeksi mengarah kepada penyakit degeneratif yang notabene lebih sulit diatasi. Penemuan antibiotik pada tahun 1948 telah menyebabkan penurunan kasus akibat infeksi akibat bakteri yang cukup signifikan, meskipun kasus infeksi akibat virus disisi lain justru 
meningkat. Infeksi akibat virus hingga kini sulit diatasi karena kesulitan dalam pembuatan antivirus, sehingga penyakit akibat virus seperti flu burung, SARS, AIDS, dan demam berdarah hingga kini masih sulit diatasi sehingga angka mortalitasnya masih tinggi.

Meningkatnya status sosio-ekonomi dan perubahan gaya hidup (life-style) menyebabkan pola diet kolesterol, asam lemak jenuh, karbohidrat dan gula sederhana meningkat, sementara aktivitas fisik makin berkurang (sedentary life style) sehingga mengakibatkan prevalensi obesitas (kegemukan) dan penyakit degeneratif di Indonesia dua dekade terakhir cenderung meningkat. Obesitas akan meningkatkan resiko terjadinya berbagai penyakit degeneratif dan gangguan psikososial. Penyakit degeneratif yang banyak dijumpai antara lain hipertensi, diabetes melitus (gula), sindrom X (hipertensi, resistensi insulin, obesitas sentral, hiperlipidemi), hiperlipidemi (kolesterol, trigliserida, LDL), stroke, penyakit jantung, stroke, dan kanker.

Globalisasi telah menyebabkan masuknya berbagai pengaruh asing yang tidak selalu bernilai positif. Ketidakmampuan individu untuk menyaring pengaruh/nilai negatif globalisasi telah menimbulkan banyak gangguan dalam hubungan antar individu termasuk hubungan dalam keluarga. Gangguan dalam hubungan keluarga sangat rentan menyebabkan anak-anak memiliki gangguan psikososial, sehingga terjadi kenaikan anakanak yang memiliki gangguan perilaku. Disisi lain angka perceraian meningkat drastis sehingga meningkatkan jumlah anak korban perceraian. Anak dari korban perceraian dan keluarga yang broken home, telah diketahui rentan terkena pengaruh narkoba dan tree-sex. Saat ini penggunaan narkoba dan free-sex meningkat di Indonesia telah meningkat pesat, sehingga meningkatkan jumlah korban HIV/AIDS dan penyakit kelamin lainnya. Sekitar 170.000 sampai 210.000 dari 220 juta penduduk Indonesia diduga mengidap HIV/AIDS. Perkiraan prevalensi keseluruhan adalah $0,1 \%$ di seluruh negeri, dengan pengecualian Provini Papua, di mana angka epidemik diperkirakan mencapai 2,4\%. Jumlah kasus kematian akibat AIDS di Indonesia diperkirakan mencapai 5.500 jiwa. Epidemi tersebut terutama terkonsentrasi di kalangan pengguna obat terlarang melalui jarum suntik dan pasangan intimnya,' orang yang berkecimpung dalam kegiatan prostitusi dan pelanggan mereka, dan pria yang melakukan hubungan seksual dengan sesama pria.

Sebagian besar penyakit degeneratif ini bersifat kronik progresif sehingga membutuhkan konseling untuk mengubah gaya hidup dengan tujuan mencegah makin parahnya penyakit dan kekambuhan. Bagi penderita penyakit terminal (yangsulit untuk disembuhkan), seperti kanker stadium akhir, jantung derajat berat, gagal ginjal terminal dan sebagainya, konseling selain untuk mengurangi kecemasan/ depresi, juga bertujuan paliatif yaitu mengurangi penderitaan pasien. Perasaan tenang dan pasrah dapat mengurangi rasa sakit yang ditimbulkan penyakit.

Bertambahnya jumlah dan kualitas manusia telah meningkatkan kompetisi manusia dalam mendapatkan pendidikan dan pekerjaan. Keadaan ini menyebabkan makin tingginya angka kejadian gangguan psikosomatis dan keluhan fisik/somatis yang disebabkan masalah psikis/emosi seperti gangguan somatoform, hipokondriasis, dan sebagainya. Gangguan psikosomatis adalah kondisi psikologis dan emosional yang menimbulkan gangguan fisik. 
Berdasarkan data dari Departemen Penyakit Dalam FKUI, penderita psikosomatis mencapai 50\% dari jumlah pasien. Bahkan 15- 30 persen orang meninggal dunia karena gangguan psikosomatis di Jakarta (Kompas, 24 Juli 2009).

Pelaksanaan konseling (helping relationship) sebenarnya bukan hanya terjadi dalam setting pendidikan (formal) saja, tetapi juga dalam semua bidang kehidupan dimana terjadi hubungan antar manusia dengan manusia. Dengan kata lain bila ada interaksi antara individu dengan individu lain yang membutuhkan bantuan, maka akan terjadi hubungan yang membantu. Hubungan yang membantu dan hubungan konseling adalah sama. Tujuannya adalah untuk menumbuhkan, mengembangkan, dan membantu individu yang membutuhkan (W'illis, 2000). Natawidjaya (2000:77) juga menyatakan bahwa "Pada masa yang akan datang, tenaga konselor dan praksis bimbingan dan penyuluhan tidak hanya terbatas pada tatanan sekolah, melainkan pada tatanan masyarakat yang lebih luas, dimana sekolah hanya merupakan salah satu bagian dari tatanan masyarakat tersebut." Apalagi dengan adanya program Pendidikan Profesi Konselor, nampaknya harapan masyarakat terhadap profesi konselor makin tinggi atau dengan kata lain konselor akan memiliki nilai jual yang tinggi pula.

Meskipun demikian, berdasarkan redefinisi konteks tugas konselor, berkembang visi dan misi layanan ahli bimbingan dan konseling yaitu dalam konteks" manusia belajar sepanjang hayat yang membutuhkan berbagai jenis layanan yang juga bercakupan sejagat hayat", sehingga dipersepsikan mampu menangani nyaris keseluruhan permasalahan hidup yang dihadapi umat manusia, setidaknya manusia Indonesia, mulai bidang pendidikan, karier, masalah perkawinan, ketenagakerjaan, bahkan merambah masalah kelainan kejiwaan, rehabilitasi mental napi, bahkan gangguan jiwa akut. Namun dengan masa belajar yang sangat terbatas, maka redefinisi niche/habitat konselor profesional yang terbaik membatasi wilayah layanan yaitu mencakup "wilayah layanan yang bertujuan memandirikan individu yang normal dan sehat dalam menavigasi perjalanana hidup melalui pengambilan keputusan termasukyang terkait dengan keperluan untuk memilih, meraih serta mempertahankan karier uantuk mewujudkan kehidupan yang produktif dan sejahtera,serta menjadi warga masyarakat yang peduli kemaslahatan umum melalui pendidikan". Dengan demikian peran konselor di Indonesia saat ini dibatasi hanya dalam konteks jalur pendidikan formal.

Salah satu setting di luar jalur pendidikan yang membutuhkan konseling adalah bidang kedokteran/ kesehatan. Konseling di bidang kesehatan selama ini telah dilakukan baik oleh dokter umum, psikiater (juga melakukan psikoterapi bagi kasus yang berat), dan perawat. Namun konseling yang dilakukan selama ini tanpa didasari tekning konseling yang baik. Individu yang didiagnosis dokter menderita suatu penyakit berat atau sulit disembuhkan, biasanya akan mengalami kecemasan. Pengobatan yang lama, mahal, dan kerapkali menyakitkan tanpa keyakinan kepastian kesembuhan, akan menimbulkan kecemasan. Kecemasan yang timbul biasanya justru akan memperparah penyakitnya. Penelitian telah menunjukkan, kecemasan akan meningkatkan kadar hormon stress (kortisol) yang selanjutnya menurunkan daya tahan terhadap penyakit melalui depresi sel 
T, sehingga justru mempersulit penyembuhan (Heryati, 2006). Disimlah perlunya konseling, bersinergi dengan pengobatan medis dalam membantu kesembuhan penderita. Selain itu konseling juga dibutuhkan untuk mengubah gaya hidup dengan tujuan mencegah makin parahnya penyakit dan kekambuhan. Bagi penderita penyakit terminal (yang sulit untuk disembuhkan), seperti kanker stadium akhir, jantung derajat berat, gagal ginjal terminal dan sebagamya, konseling selain untuk mengurangi kecemasan/depresi, juga bertujuan paliatif yaitu mengurangi penderitaan pasien. Perasaan tenang dan pasrah dapat mengurangi rasa sakit yang ditimbulkan penyakit.

\section{PEMBAHASAN}

\section{Konsep Sehat dan Kesehatan Jiwa}

Sehat merupakan sebuah keadaan sehat yang meliputi seluruh aspek kehidupan manusia yaitu fisik, emosi, sosial dan spiritual, tidak tidak hanya terbebas dari penyakit.dan kecacatan. Menurut WHO (1947) Sehat itu sendiri dapat diartikan bahwa suatu keadaan yang sempurna baik secara fisik, mental dan sosial serta tidak hanya bebas dari penyakit, kecacatan atau kelemahan (WHO, 1947).

Definisi WHO tentang sehat mempunyai karakteristik berikut yang dapat meningkatkan konsep sehat yang positif (Edelman dan Mandle. 1994):

1. Memperhatikan individu sebagai sebuah sistem yang menyeluruh.

2. Memandang sehat dengan mengidentifikasi lingkungan internal dan eksternal.

3. Penghargaan terhadap pentingma peran individu dalam hidup.

UU No.23,1992 tentang Kesehatan menyatakan bahwa: kesehatan adalah keadaan sejahtera dari badan, jiwa dan sosial yang memungkinkan hidup produktif secara sosial dan ekonomi. Dalam pengertian ini maka kesehatan harus dilihat sebagai satu kesatuan yang utuh terdiri dari unsur-unsur fisik, mental dan sosial dan di dalamnya kesehatan jiwa merupakan bagian integral kesehatan. Pendekatan yang digunakan pada abad ke-21, sehat dipandang dengan perspektif yang lebih luas. Luasnya aspek itu meliputi rasa memiliki kekuasaan, hubungan kasih sayang, semangat hidup, jaringan dukungan sosial yang kuat, rasa berarti dalam hidup, atau tingkat kemandirian tertentu (Haber, 1994). Paradigma baru sehat meliputi kesehatan jiwa (WHO, 1984; APA' 1992) menyatakan sehat jiwa adalah sehat secara biologi, psikologi, sosial, dan spiritual (Hawari, 2008)

Dalam pengertian yang paling luas sehat merupakan suatu keadaan yang dinamis dimana individu menyesuaikan diri dengan perubahan-perubahan lingkungan internal (psikologis, intelektual, spiritual dan penyakit) dan eksternal (lingkungan fisik, social, dan ekonomi) dalam mempertahankan kesehatannya. Derajat kesehatan masyarakat yang disebut sebagai psychosocial somatic health wcll being, merupakan resultan dari 4 faktor, yaitu: 1) lingkungan, 2) perilaku, 3) heredity atau keturunan, dan 4) health care service (Soejoeti, 2003). Model yang saat ini banyak digunakan untuk menjelaskan konsep sehatsakit adalah model Agen-Pejamu-Lingkungan. Menurut pendekatan model ini tingkat sehat 
dan sakit individu atau kelompok ditentukan oleh hubungan dinamis antara Agen, Pejamu, dan Lingkungan (lihat gambar 1).

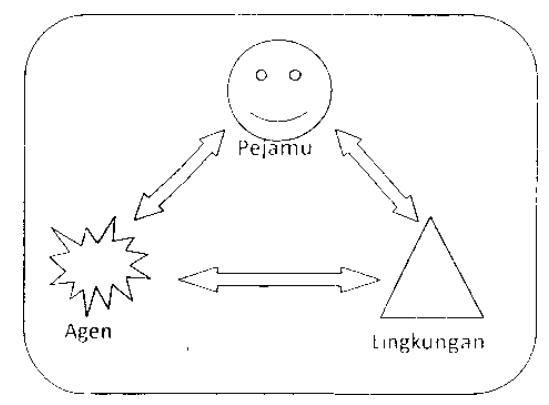

Gambar 1. Model Agen-Pejamu-Lingkungan

Keterangan:

1. Agen: Berbagai faktor internal-eksternal yang dengan atau tanpanya dapat menyebabkan terjadinya penyakit atau sakit. Agen ini bisa bersifat biologiskimia, fisik, mekanis, atau psikososial. Jadi Agen ini bisa berupa yang merugikan kesehatan (bakteri, virus, stress/kecemasan) atau yang meningkatkan kesehatan (nutrisi, dll).

2. Pejamu: Seseorang atau sekelompok orang yang rentan terhadap penyakit/sakit tertentu. Faktor pejamu antara lain: situasi atau kondisi fisik dan psikososoial yang menyebabkan seseorang yang beresiko menjadi sakit. Misalnya: Riwayat keluarga, usia, gaya hidup, dan lain sebagainya.

3. Lingkungan: Semua faktor yang ada di luar pejamu.

a. Lingkungan fisik: tingkat ekonomi, iklim, kondisi tempat tinggal, sanitasi lingkungan, penerangan, tingkat kebisingan, dan lain sebagainya.

b. Lingkungan sosial: Hal-hal yang berkaitan dengan interaksi sosial, misalnya: stress, konflik, kesulitan ekonomi, krisis hidup.

\section{Fungsi Konseling}

Dalam bidang kesehatan/kedokteram konseling berfungsi:

\section{Preventif}

Konseling berfungsi memberikan informasi untuk mencegah perilaku yang tidak sehat atau mencegah timbulnya masalah misal mencegah masalah dalam pernikahan.

2. Kuratif

3. Konseling berfungsi menyembuhkan keluhan fisik yang diakibatkan masalah psikis/psikososial (psikosomatis) atau pada. Selain itu juga untuk mengurangi depresi atau pada kecemasan pada penderita penyakit stadium akhir (terminal ill) atau penyakit yang sulit disembuhkan.

4. Promotif

Konseling berfungsi membantu meningkatkan derajat kesehatan pasien. 


\section{Konseling Kesehatan}

\section{Konseling Pre-Marital (Pra-nikah)}

Konseling pra-nikah dimaksudkan untuk membantu pasangan calon pengantin untuk menganalisis kemungkinan masalah dan tantangan yang akan muncul dalam rumah tangga mereka dan membekali mereka kecakapan untuk memecahkan masalah. Konseling pra-nikah juga sebagai wahana membimbing dua orang yang berbeda untuk saling berkomunikasi, belajar menyelesaikan masalah dan mengelola konflik. Keterampilan ini jelas-jelas sangat penting dalam perjalanan kehidupan rumah tangga. Pasangan muda sangat membutuhkan konseling terutama untuk memperjelas harapanharapan mereka pada pernikahannya dan memperkuat hubungan sebelum menikah.

Konseling pra-nikah akan membantu mereka melihat pernikahan dan rumah tangga secara realistis, mendorong mereka mempertanyakan ulang apa yang sebetulnya mereka sebut pernikahan dan membantu mereka menemukan persamaan yang mungkin menjadi sebab mereka hidup bersama. Konselor (penasihat) bukanlah orang yang akan menyelesaikan semua masalah yang mereka hadapi. Ia hanya orang ketiga yang menjadi perantara dan menyodorkan cara-pandang lain dalam mengeksplorasi hubungan mereka.

Selain itu juga dilakukan pemeriksaan kesehatan terutama untuk mengetahui kemungkinan kondisi kesehatan anak yang akan dilahirkan. Dengan pemeriksaan kesehatan dapat diketahui riwayat kesehatan kedua belah pihak, termasuk soal genetik, penyakit kronis, hingga penyakit infeksi yang dapat mempengaruhi kondisi kesehatan keturunan.

\section{Konseling Kesehatan Reproduksi Remaja (KRR)}

Merupakan konseling untuk membantu remaja agar memiliki pengetahuan, kesadaran sikap dan perilaku seksual yang bertanggung jawab, jumlah remaja di Indonesia yaitu mereka yang berusia 10-19 tahun adalah sekitar 30 persen dari jumlah penduduk atau lebih kurang 65 juta jiwa. Perilaku kesehatan reproduksi remaja saat ini cenderung kurang mendukung terciptanya remaja berkualitas. Angka aborsi dikalangan remaja tergolong tinggi, diperkirakan sekitar 700 sampai 800 ribu kasus per tahun. Tingkat kelahiran dimasa remaja (adolescence pregnancy) juga masih relatif tinggi yaitu sekitar 11 persen dari seluruh kelahiran yang terjadi. Persentase remaja yang terjangkit penyakit menular seksual (PMS) serta HIV/AIDS cenderung meningkat.

Disamping itu tingkat anemia di kalangan remaja masih sekitar 40-45 persen, padahal anemia sangat berbahaya bagi kehamilan dan proses persalinan. Permasalahan utama kesehatan reproduksi remaja (KRR) di Indonesia kurangnya informasi mengenai kesehatan repoduksi, masalah pergeseran perilaku seksual remaja, pelayanan kesehatan yang kurang baik serta perundang-undangan yang belum mendukung.

\section{Konseling Keluarga Berencana (KB)}

Konseling KB bertujuan membantu klien membuat pilihan metoda kontrasepsi yang tepat bagi diri sendiri dan mendapatkan solusi berbagai masalah kesehatan 
reproduksi. Klien juga diharapkan untuk dapat membagi informasi mengenai $\mathrm{KB}$ kepada wanita usia subur lainnya.

\section{Konseling HIV/AIDS}

Konseling HIV/AIDS merupakan komunikasi yang bersifat rahasia antara klien dan konselor. Konseling bertujuan meningkatkan kemampuan penderita penderita stres dan mengambil setiap keputusan berkaitan dengan penyakit HIV/AIDS. Proses konseling termasuk evaluasi risiko personal penularan HIV, fasilitasi pencegahan perilaku dan evaluasi penyesuaian diri ketika klien menghadapi hasil tes positif (WHO).

Tujuan konseling HIV/AIDS adalah sebagai berikut.

a. Menyediakan dukungan psikologis, misalnya: dukungan yang berkaitan dengan kesejahteraan emosi, psikologis, sosial dan spiritual seseorang yang mengidap virus HIV atau virus lainnya.

b. Pencegahan penularan HIV dengan menyediakan informasi tentang perilaku berisiko (seperti seks aman atau penggunaan jarum bersama) dan membantu orang dalam mengembangkan keterampilan pribadi yang diperlukan untuk pe $\neg$ mbahan perilaku dan negosiasi praktek lebih aman.

c. Memastikan efektivitas rujukan kesehatan, terapi, dan perawatan melalui pemecahan masalah kepatuhan berobat.

\section{Psikosomatis}

Istilah psikosomatis dipelopori oleh seorang pionir kedokteran psikosomatis, yaitu Flanders Dunbar pada tahun 1943. Psikosomatis merupakan gangguan yang bersilat fisik tapi tidak dapat ditemukan sebab-sebab organis atau medisnya, namun faktor-faktor psikologis yang diduga kuat sebagai pola penyebabnya. Kecurigaan psikosomatis biasanya karena tidak ditemukan kelainan baik fisik maupun pada pemeriksaan penunjang, selain itu keluhan tidak membaik dengan berbagai obat- obatan yang sudah diberikan. Pada umumnya kelainan psikosomatis disebabkan oleh aktivitas yang berlebih pada sistem simpatis atau sistem parasimpatis.

Diagnostik pasti psikosomatis memerlukan hal-hal berikut:

a. Ada gejala bangkitan otonomik, misal : palpitasi, berkeringat, tremor, muka merah;

b. Ada gejala subyektif tambahan : mengacu sistim organ tertentu;

c. Preokupasi dengan distress(sering tidak begitu khas);

d. Tidak terbukti gangguan bermakna pada struktur dan fungsi organ yang dimaksud (hasil pemeriksaan organdaiam batas normal).

Diagnosa psikosomatis berdasarkan Pedoman Penggolongan Diagnosa Gangguan Jiwa III, Kode Diagnosis (ICD 10: F. 45. Dalam PPDGJ III, psikosomatis tidak diklasifikasikan secara tersendiri. Dalam DSM-IV, istilah psikosomatik digantikan dengan kategori diagnostik "faktor psikologis yang mempengaruhi kondisi medis" (Hervati, 2006). 
Mekanisme terjadinya psikosomatis melalui dua jalur, yaitu sebagai berikut.

\section{a. Sistem saraf otonom}

Efek sistemik simpatis, yang biasa timbul: peningkatan frekuensi denyut jantung, peningkatan tekanan arteri, konstipasi, peningkatan kecepatan metabolisme. Sedangkan efek sistem parasimpatis yang lebih bersifat setempat, contohnya : peningkatan atau penurunan denyut jantung, spasme esophageal, peningkatan peristaltik dari traktus gastrointestinal bagian atas, peningkatan kadar asam lambung sehingga dapat timbul ulkus peptikum, sekresi kelenjar kolon yang ekstrem dan peristaltik sehingga menyebabkan diare.

Keaadan emosi (misal marah) -> perangsangan hipotalamus -> sinyal diteruskan ke bawah melalui tormasio retikularis dan medulla spinalis $->$ lepasnya muatan-muatan simpaiis efek-efek simpatis terjadi. Peristiwa simpatetik ini merupakan alarm reaction atau reaksi tanda bahaya pada respon 'flight ur fight' (respon menyerang atau menghindar). Perangsangan saraf simpatis yang menuju ke medulla adrenal -> lepasnya epinetr i n dan norepinefrin -> masuk sirkulasi darah -> sampai di semua jaringan tubuh -> timbul efek-efek dari kedua hormon tersebut (peningkatan aktivitas jantung, melebarnya pupil, konstriksi seluruh pembuluh darah, dll).

b. Hipofisis anterior :

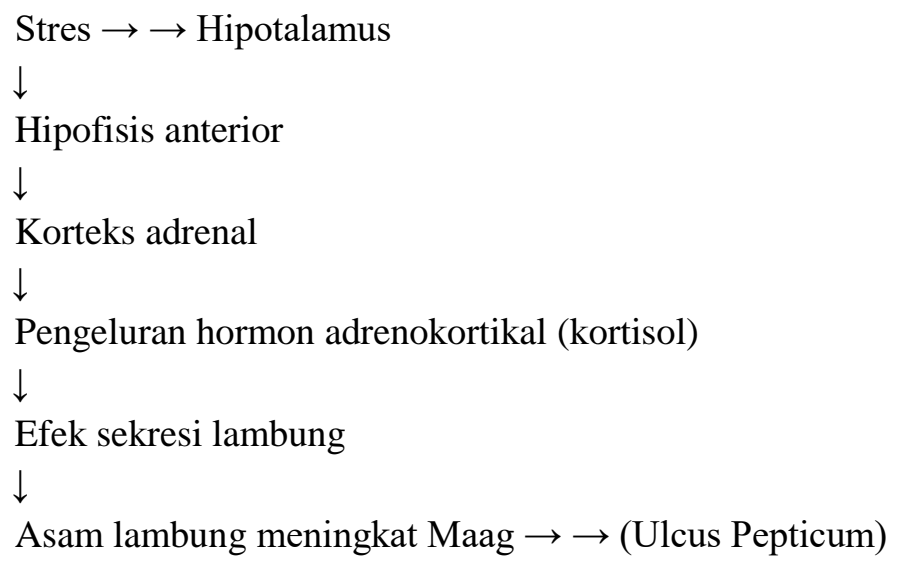

\section{Pendekatan Konseling dalam Bidang Kesehatan}

Hubungan dokter-pasien seharusnya merupakan hubungan yang membantu (helping relationship). Artinya dokter sebagai tenaga profesional di bidang kesehatan hendaknya membantu dengan ikhlas dan kerelaan kepada pasiennya. Masalah yang dihadapi dokter dan perawat bukan mengenai profesinya, melainkan kemampuan berkomunikasi dengan pasien. Dokter dan perawat yang mampu berkomunikasi dengan baik kepada pasiennya akan mempercepat kesembuhan dan mencegah kekambuhan penyakit. Cara komunikasi yang dimaksud adalah dialog dua arah (non- direktif), bukan dialog searah yang berupa instruksi dokter kepada pasien, tetapi dialog yang membuat pasien menjadi terbuka kepada dokter, bersedia memberikan informasi yang diperlukan, menyatakan semua keinginan, 
kecemasan, permasalahan lain yang dihadapi berkaitan dengan penyakitnya, dan sebagainya, yang kemudian ditanggapi dokter dengan positif, ramah, dan bersahabat.

Sementara penderita penyakit terminal, atau penyakit degeneratif kronis, biasanya mengalami kecemasan atau depresi yang justru akan memperberat penyakitnya. Di sini konseling berperan penting membantu penderita menghadapi penyakitnya. Salah satu landasan bimbingan dan konseling adalah landasan religius. Landasan ini menekankan tiga hal pokok, yaitu: (a) manusia sebagai makhluk Tuhan; (b) sikap yang mendorong perkembangan dari perikehidupan manusia berjalan ke arah dan sesuai dengan kaidahkaidah agama; dan (c) upaya yang memungkinkan berkembang dan dimanfaatkannya secara optimal suasana dan perangkat budaya (termasuk ilmu pengetahuan dan teknologi) serta kemasyarakatan yang sesuai dengan dan meneguhkan kehidupan beragama untuk membantu perkembangan dan pemecahan masalah.

Ditegaskan pula oleh Moh. Surya (2006) bahwa salah satu tren bimbingan dan konseling saat ini adalah bimbingan dan konseling spiritual. Berangkat dari kehidupan modern dengan kehebatan ilmu pengetahuan dan teknologi serta kemajuan ekonomi yang dialami bangsa-bangsa Barat yang ternyata telah menimbulkan berbagai suasana kehidupan yang tidak memberikan kebahagiaan batiniah dan berkembangnya rasa kehampaan. Dewasa ini sedangberkembang kecenderungan untuk menata kehidupan yang berlandaskan nilai-nilai spiritual. Kondisi ini telah mendorong kecenderungan berkembangnya bimbingan dan konseling yang berlandaskan spiritual atau religi.

Teknik konseling yang dipergunakan dalam bidang kesehatan, disesuaikan dengan tujuan atau fungsinya. Teknik konseling yang dapat digunakan dalam bidang kesehatan antara lain konseling eksistensialis, Cognitif Behavioral Terapi (CBT), dan konseling spiritual.

\section{Konseling berdasarkan Filsafat Eksistensialis, seperti Logoterapi}

Filsafat eksistensialis menganggap kematian adalah suatu esensi untuk menemukan makna dan tujuan hidup. Hidup memiliki makna karena hidup harus berakhir, sehingga hidup akan diperkuat jika kita mengambil realitas hidup yang telah kita miliki secara serius. Realitas ketidaklanggengan hidup menstimulasi kita untuk melihat prioritas untuk melihat prioritas tujuan hidup yang kita miliki, sehingga dapat memilih mana yang memiliki nilai paling tinggi. Masa kini sangat berarti karena merupakan milik kita yang nyata, serta merupakan hakikat kesementaraan yang membuat kita merasa perlu berbuat sesuatu dengan hidup kita, membuat pilihan, mencoba menjadi pribadi yang kita inginkan. Jika kita secara emosional menerima kenyataan bahwa akhirnya kita semua akan mati, kita akan menyadari lebih jelas bahwa tindakan kita diperhitungkan, bahwa kita benar-benar memiliki pilihan, dan bahwa kita harus menerima tanggungjawab akhir mengenai betapa baiknya hidup kita (Corey and Corey, 2006).

Salah satu teknik konseling beraliran filsalat eksistensialis yang menekankan makna hidup adalah logoterapi dari Viktor E. Frankl. Frankl memperkenalkan logoterapi yang mengakui adanya dimensi spiritual dan memanfaatkannya untuk 
mengembangkan hidup bermakna (therapy through meaning). Dari asal katanya, logoterapi berasal dari kata 'logos' yang berarti 'meaning' (makna) dan 'spirituality' (kerohanian). Logoterapi berpandangan bahwa 'makna hidup' (the meaning of life) dan 'hasrat untuk hidup bermakna' (the will to meaning) merupakan motif azasi manusia yang dapat dilihat dalam dimensi spiritual atau 'noetic'. Jadi, Frankl berpendapat bahwa ada dimensi lain selain dimensi somatik dan psikis, yaitu dimensi spiritual.

Tampaknya Frankl tidak memisahkan antara fisik, psikis dan spiritual seorang manusia dan menganggapnya merupakan satu kesatuan yang utuh. Konflik dasar spiritual yang muncul dari dalam diri seseorang dapat terjadi sebagai akibat ketidakmampuannya untuk muncul secara spiritual mengatasi kondisi fisik dan psikisnya. Konflik ini tidak berakar pada kerumitan psikologis, akan tetapi terpusat pada hal spiritual dan etis. Apabila terdapat satu konflik spiritual dapat menyebabkan gangguan psikologis (neurosis) yang disebut Frankl sebagai 'noogenic neurosis'. Terapi ini bertujuan untuk memenuhi doroangan spiritual yang dibawa oleh manusia sejak lahir dengan mengeksplorasi makna keberadaan manusia.

Konsep logoterapi, yaitu sebagai berikut.

a. Kehidupan memiliki makna dalam keadaan apapun, termasuk dalam penderitaan.

b. Manusia memiliki suatu kehendak untuk hidup bermakna yang merupakan motivasi utama untuk hidup.

c. Kita memiliki kebebasan untuk menemukan makna hidup melalui apa yang dikerjakan, apa yang dihayati, atau sekurang-kurangnya dalam sikap yang kita ambil atas situasi dan penderitaan yang tak dapat diubah lagi.

Ajaran dalam Logoterapi mempunyai 3 landasan filsafat, yaitu :

a. The freedom of will: kebebasan tetapi terbatas, bukan kebebasan dari sesuatu tetapi kebebasan mengambil sikap terhadap sesuatu. Kebebasan yang dimaksud di sini adalah kebebasan yang bertanggung jawab.

b. The will to meaning: merupakan motivasi dasar manusia, yang dimaksudkan dengan keinginan untuk bermakna adalah : tertuju kepada hal-hal yang berada di luar diri manusia tersebut, bukan berpusat pada diri sendiri (self-centered)

c. The meaning of life: dapat ditemukan oleh manusia dalam kehidupannya, termasuk pada saat mengalami penderitaan (rasa bersalah, sakit, kematian). Makna hidup setiap orang sifatnya unik, personal, spesifik, dan temporer. Makna hidup tidak dapat diberikan oleh siapapun, jadi harus ditemukan oleh diri sendiri.

\section{Konseling Cognitif Behavioral Terapi (CBT).}

Terapi Cognitive-Behavioral Therapy (CBT) atau Terapi Kognitif-Perilaku merupakan salah satu bentuk konseling yang bertujuan membantu klien agar dapat menjadi lebih sehat, memperoleh pengalaman yang memuaskan, dan dapat memenuhi gaya hidup tertentu, dengan cara memodifikasi pola pikir dan perilaku tertentu. Pendekatan kognitif berusaha memfokuskan untuk menempatkan suatu pikiran, keyakinan, atau bentuk pembicaraan diri (self-talk) terhadap orang lain. Selain itu, 
terapi juga memfokuskan pada upaya membelajarkan klien agar dapat memiliki cara berpikir yang lebih positif dalam berbagai peristiwa kehidupan dan tidak hanya sekedar berupaya mengatasi penyakit atau gangguan yang sedang dialaminya. Dengan kata lain, konseling kognitif memfokuskan pada kegiatan mengelola dan memonitor pola fikir klien sehingga dapat mengurangi pikiran negatif dan mengubah isi pikiran agar dapat diperoleh emosi yang lebih positif (Natawidjaya, 2007).

Dalam Terapi Kognitif-Behavioral (TKB), konselor dan klien bekerjasama untuk mengidentifikasi dan mengubah pola pikir dan perilaku negatif yang menyebabkan timbulnya gangguan fisik-emosional. Fokus dalam terapi ini adalah berusaha mengubah pikiran atau pembicaraan diri (self-talk). Proses Terapi Kognitif-Behavioral (TKB) membantu klien dalam mengidentifikasi dan memperbaiki kesalahan spesifik dari apa yang dia pikirkan dan menyebabkan timbulnya perasaan negatif dan menyakitkan. Setiap bentuk pemikiran yang menyimpang klien ini dapat mempengaruhi tingkat emosi dan perilakunya.

Dalam memperlakukan orang yang mengalami kesulitan psikologis, titik yang paling efektif untuk dilakukan intervensi adalah pada tingkat pikiran yang menimbulkan rasa sakit tersebut. Jika proses berpikirnya dapat berhasil dirubah, (misalnya asumsi, keyakinan, nilai-nilai), maka dengan sendirinya perubahan dalam emosi dan perilaku akan mengikutinya.

Beberapa teknik dan strategi behavioral therapy dapat digunakan untuk meningkatkan hasil perawatan (misalnya, teknik mengelola kemarahan, meditasi, latihan relaksasi, dan assertive training, dan sebagainya). Tidak seperti proses konseling tradisional umurnya, Terapi Kognitif-Perilaku lebih memfokuskan pada hasil dan tujuan, termasuk didalamnya adalah hasil jangka pendek (segera) dari proses konseling yang sedang berjalan, yaitu tercapainya pengalaman positif klien yang relatif cepat dengan adanya kemajuan perasaan yang lebih lega dan daya tahan.

\section{Konseling Spiritual}

Pada dekade 2000 dipandang perlu pendekatan kecerdasan emosi/ ESQ dalam pelayanan konseling. Dalam proses konseling, konselor menjalin hubungan dengan klien dan klien memperbaiki hubungannya baik dengan Tuhan, sesama manusia dan alam semesta. Adanya konseling spiritual yang diprogramkan secara formal dengan dasar-dasar ilmiah pada kesehatan mental dan penyembuhan penyakit jiwa, pelaksanaannya didasari dengan berbagai disiplin ilmu, psikoterapi, faith healing (penyembuhan melalui keimanan) dan prinsip religio-psychotherapy dijadikan pegangan dalam pendekatan keimanan (Sudrajat, 2008). Pendekatan konseling spiritual dapat berupa konseling islami atau pastoral. 
94 | Rosmalina - Kolaborasi Konseling dengan ...

\section{SIMPULAN}

Pada kasus psikosomatis konseling sangat penting untuk mencari sumber kecemasan yang menjadi pemicu timbulnya gangguan fisik. Biasanya dokter akan merujuk ke psikiater atau psikolog. Namun banyak pasien yang menolak dengan alasan tidak memiliki gangguan kejiwaan. Hal lain disebabkan karena adanya stigma bahwa psikiater hanya mengobati orang yang sakit jiwa (gila). Sehingga dengan tujuan untuk mempercepat kesembuhan, mencegah kekambuhan penyakit, dan mencegah ketergantungan pada obat penenang, seorang dokter haruslah memiliki ketrampilan konseling.

\section{DAFTAR PUSTAKA}

Corey, G. (2005). Theory and practice of Counseling and Psychoterapy. Australia: Thomson Brokks Cole.

Corey, G. F. and Corey, M. S. (2006) Group: Process and Practice. Monterey, CA: Brooks/Cole.

Hawari, D. (2009). Membangun karakter bangsa dalam perspektif medis, psikologis, budaya, dan agama. Disajikan dalam kuliah umum Pasca Sarjana UPI.

Heryati, E. (2006). Diktat kuliah Psikologi Faal. Tidak diterbitkan.

Kaplan, H.I., Sadock, B.J., Grebb, J.A. (1997). Sinopsis Psikiatri: Ilmu Pengetahuan Perilaku Psikologi Klinis. Jakarta: Binarupa Aksara.

Natawidjaya, R. (2000). Reposisi program Bimbingan dan Penyuluhan dalam menjawab tantangan masa depan. Jurnal Psikopedagogia.

Natawidjaya, R. (2007). Konseling Kelompok: Konsep Dasar dan Pendekatan. Bandung: Rizqi Press.

Prayitno, dkk. (2004). Pedoman Khusus Bimbingan dan Konseling. Jakarta: Depdiknas.

Soenanti, S.Z. (2005). Konsep sehat, sakit, dan penyakit dalam konteks sosial budaya. Jakarta: Cermin Dunia Kedokteran (vol. 149).

Sudrajat, A. (2008). Terapi Kognitif-Behavioral. Akses : http/www. Ahmad Sudrajat. wordpress.com/(diunduh 10 November 2009).

Surya, M. (2006). Profesionalisme Konselor dalam Pelaksanaan Kurikulum Berbasis Kompetensi (makalah). Majalengka: Sanggar BK SMP, SMA dan SMK.

Willis, S.S. (2009). Konseling Individual: Teori dan Praktek. Bandung: Alfabeta. 